\title{
Spatial Differentiation of Poverty in Polish Voivodships
}

\author{
Małgorzata Ćwiek ${ }^{1}$, Katarzyna Maj-Waśniowska² ${ }^{2}$ Katarzyna Stabryła-Chudzio ${ }^{3}$
}

Submitted: 11.03.20. Accepted: 25.08.20

\section{Abstract}

Purpose: This study aims to assess the direction of changes in the extent of extreme, relative, and statutory poverty in 2008-2017 in Poland, along with the spatial differentiation of poverty in individual voivodships.

Methodology: The study of poverty differentiation based on data from Household Budgets Survey. Obtained results were subjected to statistical analysis, using elements of multidimensional analysis.

Results: The research revealed that there are significant differences in the level of poverty in individual voivodships, with lower values observed in Western Poland. A significant drop in the level of poverty, especially extreme poverty, was recorded in 2008-2017. Furthermore, fluctuations in the extent of poverty are strongly impacted by state policy.

Implications: Research results may be useful to policy-makers at the local government level not only in Poland but also in other countries, mainly from the perspective of the European Union's Europe 2020 strategy.

Originality/Value: The article undertakes the topic of poverty, which constitutes an important and current socioeconomic concern. Despite progressive economic development, there still exist disadvantaged groups of entities and households.

Keywords: poverty, spatial differentiation of poverty, Polish voivodships, public policy.

JEL: I32, J18, R59

\footnotetext{
1 Department of Statistics, College of Economics, Finance and Law, Cracow University of Economics, 31-510 Cracow, 27 Rakowicka St., Poland, https:// orcid.org/0000-0002-6375-098X, e-mail: malgorzata.cwiek@uek.krakow.pl.

2 Department of Public Finance, College of Economics, Finance and Law, Cracow University of Economics, 31-510 Cracow, 27 Rakowicka St., Poland, https:// orcid.org/0000-0003-0312-3359, e-mail: katarzyna.maj@uek.krakow.pl.

3 Department of Finance and Financial Policy, College of Economics, Finance and Law, Cracow University of Economics, 31-510 Cracow, 27 Rakowicka St., Poland, https:// orcid.org/0000-0001-9975-1899, e-mail: stabrylk@uek.krakow.pl.
} 


\section{Introduction}

Poverty is an important and current socioeconomic problem. Despite the progressing economic development and growing prosperity, there remain disadvantaged groups of entities and households. The literature on the subject analyzes broadly understood problems of poverty in various aspects. Both causes and effects of this social problem are examined. This phenomenon has a multidimensional character and varied factors that impact its distribution. The implementation of an effective social policy with the aim to reduce poverty requires not only monitoring its changes over time but also in-depth analyses at a regional or even local level. Current research indicates the geographical location and class of place of residence as some of the determinants for the occurrence of poverty.

The spatial approach in measuring poverty is important for the effectiveness of the European Union's cohesion policy and, consequently, for translating its objectives into programs implemented in Member States. Although so far, indicators closely related to poverty have not determined the distribution of funds between EU members and EU regions, we should note that the Europe 2020 strategy foregrounds the reduction of poverty and social exclusion as one of the basic objectives. In the context of the economic and social crisis caused by the SARS-CoV-2 pandemic, we may conclude that the fight against poverty at the EU level will not end in 2020 but will continue in the years to come. As a result, the European Commission should include poverty-related measures by planning to divide cohesion policy funds into national envelopes for the next seven years.

The following research questions underlie the problem discussed in the study. 1) What are the determinants and correlates of poverty occurrence and how to measure them? 2) Has the range of extreme, relative, and statutory poverty in Poland changed in 2008-2017? 3) What is the scale of spatial differentiation of poverty level in Poland among individual voivodships? To answer the above questions, we set the main objectives of the study: 1) the identification of factors determining the occurrence of poverty; 2) the assessment of changes in the extent of extreme, relative, and statutory poverty in 2008-2017 in Poland; 3) spatial differentiation characteristics of the level of poverty in individual voivodships in Poland.

As part of the review, we employed a critical analysis of the literature on the subject and a synthesis of present studies. The empirical part of the research based on data from Statistics Poland. The obtained results were subjected to statistical analysis, using elements of multidimensional analysis, i.e. cluster analysis with the Ward method. 
The structure of the study stems from the abovementioned objectives. The first part includes the literature review on causes and types of poverty and ways of its measurement. In the second part, we will discuss the methodology of conducted research, while the third part will demonstrate the results that allowed us to provide answers to the research question. The article concludes with a summary, which contains the most important conclusions of analyses and identifies potential directions for further research.

Due to the unavailability of data, this article only considers the topic of the extent of poverty, without analyzing the differentiation of the depth and severity of poverty in Polish households.

\section{Factors That Determine Poverty and Ways of Measurement}

The literature on the subject defines poverty in many different ways, both on the grounds of economy and sociology. Moreover, these definitions recently included newer and newer dimensions, such as owned property, health, or social origin. Thus, we witness a departure from the description of poverty only in the context of income. However, this does not mean abandoning the old categories that define poverty but only a broader study of its causes and correlates (Nalaskowski, 2007). Furthermore, in this case, the literature emphasizes the difficulty of the unambiguous definition of reasons for poverty, which we may also treat as its results. Among the most frequently mentioned determinants, scholars indicate individual factors such as the level of education, the intensity of work in the household, or the lack of employment, source of income, health (disability, chronic diseases), or - more broadly - psychophysical condition (including resourcefulness, addictions, pathologies, automatic inheritance of poverty), the size of household (including the number of children and the elderly; single-parent families), age, ethnicity (Szymkowiak et al., 2014).

Szarfenberg (2012) defines the reasons and results of poverty as correlates - thus with no indication of what is the cause and what is the effect - which are to be only a link between poverty and other factors. Besides the abovementioned individual factors, the literature mentions structural correlates: the inefficiency of the social assistance system, low social benefits, high labor costs (tax wedge size), high living costs, and housing conditions. We should emphasize that there are still such factors as the place of residence (including geographical conditions) that often results in structural correlates (the lack of family support and inadequate social security; Auleytner, 2002; Ruzik-Styrc, 2006; Lelkes et al., 2009; Szymkowiak et al., 2014) 
Therefore, we may study poverty with an objective approach - by adopting the determinants of poverty in advance - or with a subjective approach, in which it is individuals who determine which needs were not met and what income is adequate to meet them (the Leiden algorithm). Salejko-Szyszczak and Szczepaniak (2017) note that subjective poverty can result from some people's personality traits, such as laziness, the lack of will to work and study, or dishonesty. In turn, objective poverty is caused by rapid changes, such as those occurring on the job market. Other distributions of poverty - due to their duration - indicate temporary and long-term poverty (Topińska, 2008; Sączewska-Piotrowska, 2016).

In Development as Freedom, Sen (2000) also refers to age, physical characteristics, gender differences, proneness to illnesses, climatic conditions, access to public services such as education, public health, and social security, the high presence of crime, and social relations. An interesting matter appears with established behavioral patterns that may vary between communities, depending on conventions and habits. Sen underlines that being relatively poor in a wealthy community can hinder the achievement of basic goals, such as participation in community life, even if the income in absolute terms may be higher than the income level of members of poorer communities, who achieve their own objectives.

Ongoing discussions on measuring and defining the threshold of poverty result from the fact that we cannot clearly state that a given scope is appropriate or sufficient, among other things; regardless of whether the definition assumes the level of income, expenditure, or the degree of satisfaction of the group of needs, e.g. defined as basic.

Income - or expenditure-related reference in the definition of poverty will not always lead to the same results. In the case of expenditure, an entity may dispose of savings, use credits and loans, unregistered or social income. In effect, they may consume more than would result from the declared disposable income. Hence, income, expenses, and living standards do not coincide exactly. Low income constitutes only an approximation in the estimation of who is unable to meet basic needs. People can turn wealth into income and change income over time by borrowing and saving; they may consume goods free of charge or receive them in the form of a donation; they may transfer income or share the goods (Townsend, 1987; Jenkins, 2011).

As Ward notes (2009), there are many potential problems in using income alone as an indicator of purchasing power or control over resources (the need to take into consideration not only the income criterion is mentioned by Whelan and Maître, 2010, and Panek, 2010, among others). Particularly, income as such does not take into account 
accumulated savings and wealth - with the exception of interest generated by them - which can be equally used to purchase goods and services. Furthermore, since it is generally measured on an annual basis, the value reported for any period of twelve months does not take into account year-to-year fluctuations in the received amount, which may be significant for some self-employed individuals. Similarly, it does not include any income in kind in the form of, e.g., free or subsidized goods and services or food and other goods produced for own needs. Moreover, tax advantages and tax exemptions in many countries are a form of increasing income to a more acceptable level. Rusnak (2011) emphasizes that a possible solution to the controversial definitional issue could be the adoption of a multidimensional definition of poverty based on more than one determinant. As an example, the goal of the Europe 2020 strategy of reducing poverty by 20 million by 2020 is examined in terms of three sub-indicators:

- the number of people at risk of poverty: in households whose equivalent disposable income is less than $60 \%$ of the median of these incomes throughout the country;

- the number of people who cannot afford four out of nine items indicating material deprivation;

- the number of people living in households where adults (18-59-years-old) work less than $20 \%$ of the full year.

However, another problem arises here, as assumed Eurostat surveys, namely a poor person who appears in at least one dimension, which may lead to the conclusion that the number of the poor is too large; although, of course, a person appearing in more than one criterion is counted only once. In the extreme case, if only poor people who meet the criteria of all accepted dimensions were considered as poor, this number could be too low. The multidimensional approach to characterizing the phenomenon of poverty - by definition - brings poverty closer to social exclusion (Rusnak, 2011).

The multidimensional approach in measuring poverty is drawn by Ulman and Ćwiek (2014), who examine the risk of poverty in Polish households based on their biological type and place of residence. The biological type of household includes households of large families, among other things, which verifies the hypothesis that large families are at greater risk of poverty than other types. Furthermore, the risk of monetary poverty (irrespective of the biological type of household) is increasing in rural areas, while non-monetary poverty results are no longer unambiguous. Often, the risk of poverty in rural areas is lower, especially when compared to small - and medium-sized cities. 
When discussing the measurement of poverty in the European Union and proposals for new methodological approaches in the context of the Europe 2020 Strategy and the poverty reduction target, we should also refer to the publication edited by Atkinson et al. (2017), which included 26 studies conducted as part of the project "Second Network for the Analysis of EU-SILC" (Net-SILC2). Recognition of the "territorial dimension" of poverty and social exclusion is an increasingly important characteristic of the discourse and activities of the European Union (Madanipour et al., 2015).

Changes in the level of poverty are often related to the regional or local dimensions or broken down by city and village (Quintano et al., 2007; Lehtonen and Veijanen, 2012; Panek and Zwierzchowski, 2013; Molina et al., 2014; Szymkowiak, 2014; Szymkowiak et al., 2015; Sączewska-Piotrowska, 2016). We distinguish poverty and social exclusion related to rural, sparsely populated, peripheral areas with poor access to services of general interest from urban environments with high population density affected by structural changes in the economy. Based on analyses of Eurostat data, we may conclude that poverty is related to the situation in rural areas of new Member States and in the east and south of Europe, along with urban districts in the old Member States (The Territorial Dimension of Poverty, 2014). Furthermore, the authors of the report on poverty and social exclusion from Nordregio and the James Hutton Institute note that the role of space as a driving force for social exclusion is clearer in a rural rather than an urban context. Living in a remote, hard-to-reach, or sparsely populated area limits access to the labor market or education, as the lack or inadequate quality of public services and infrastructure combined with often poor or expensive public transport are factors that can worsen the feeling of social exclusion. Although individual challenges related to poverty or exposure to social exclusion may be similar in rural and urban areas, the territorial dimension should not be underestimated (The Territorial Dimension of Poverty, 2014).

Bird (2019) draws attention to similar issues in terms of unfavorable geographical location, as he mentions spatial poverty traps appearing in areas with low "geographical capital," i.e. the natural, social, political, and human capital of the area. Spatial poverty traps may lie in geographical distances (areas far from centers of political and economic activity), in areas of "low potential" or ones that are marginalized (with unfavorable ecological conditions or low agricultural or natural resources), "less privileged" (areas with the politically disadvantaged), or "poorly integrated" (areas poorly connected in terms of communication and markets).

Banerjee and Duflo (2007) conducted studies on extreme cases of poverty (extremely poor) and their identification, along with living conditions in selected countries on 
the basis of surveys in thirteen countries. These authors describe patterns of consumption and income generation, along with access to markets and public infrastructure.

Therefore, poverty is a spatially heterogeneous phenomenon whose rates can vary considerably depending on space. Consequently, the study of geographical inequalities is a very substantial dimension of poverty analysis. Regional or local policy requires a better understanding of poverty models at the right scale. Poverty can have strong local characteristics, which should be carefully considered by policy-makers as targeted policies can sometimes be more effective than general interventions (Copus et al., 2015).

Analyzing poverty in terms of voivodships, first, provides new information, which allows us to examine disparities in the extent of poverty between regions at the national level and, thus, find causes of the phenomenon that may affect government policy. Second, the regional approach is justified from the viewpoint of the EU's cohesion policy and the directing of some funds from the EU budget to reducing disparities between regions in the economic and social context. The EU cohesion policy directly and indirectly affects the level of poverty thanks to measures in support of education, lifelong learning, and training for socially excluded people. In Poland, the implementation of cohesion policy happens not only through national but also regional and interregional programs. For example, although the Eastern Poland Operational Program (Program Operacyjny Rozwój Polski Wschodniej 2007-2013, 2012; Program Operacyjny Polska Wschodnia, 2020) plans no actions directly aimed at combating poverty, discrimination, and social exclusion, it may indirectly limit the scope of these phenomena and minimize their effects.

Furthermore, indicators at the national level are useful for monitoring global trends, but disaggregated information for lower (administrative) areas is probably more exploitable. From this perspective, poverty maps that describe the spatial distribution of prosperity and poverty in a country at different levels can be used to explore the relationship between poverty and other economic, social, and geographical factors, thus becoming a useful tool for analysis and policy-making (Copus et al., 2015).

Moreover, we may study poverty in absolute and relative terms (Golinowska et al., 2005; Topińska, 2008; Haughton and Khandker, 2009). The former consists in establishing the factors that determine poverty without referring to the situation of other people (failure to meet specific needs), while the latter assumes a reference point to living conditions of other units (households). The relative approach was adopted as one of the measures of poverty by Statistics Poland (2019) and consisted in reference to average expenditure, with the poverty line set at $50 \%$ of average monthly household 
expenditure. The relative approach is characterized by the disadvantage that the improvement of the indicator thus adopted does not have to mean a real reduction in poverty, but it must result from a reduction in social inequalities.

The other two poverty thresholds adopted by Statistics Poland (2019) are absolute. The extreme poverty line, calculated by the Institute of Labour and Social Studies, is based on a minimum of subsistence, i.e. satisfying the needs absolutely necessary for life, such as food and housing; otherwise, survival is difficult, and biological destruction may occur. Let us note here that the social minimum differs from the subsistence minimum in that the former accepts the need to meet a wider set of needs; in addition to food and housing, also health, educational, transport, culture, and leisure needs. In turn, the statutory poverty line is defined in advance in Polish legislation as a monetary value entitling one to apply for a cash benefit from social assistance. The limits of extreme, relative, and statutory poverty for selected types of households in 2008-2017 are presented in Table 1.

Table 1. Poverty line for selected types of households in years 2008-2017a

\begin{tabular}{|c|c|c|c|c|c|c|c|c|c|c|c|}
\hline Poverty line & 2008 & 2009 & 2010 & 2011 & 2012 & 2013 & 2014 & 2015 & 2016 & 2017 & $\begin{array}{l}\text { Change } \\
2017 / 2008\end{array}$ \\
\hline \multicolumn{12}{|c|}{ 1-person households } \\
\hline $\begin{array}{l}\text { Extreme } \\
\text { (minimum } \\
\text { of existence) }\end{array}$ & 418 & 443 & 466 & 495 & 519 & 551 & 540 & 545 & 550 & 582 & $39.23 \%$ \\
\hline Relative & 612 & 633 & 665 & 690 & 691 & 706 & 713 & 734 & 770 & 799 & $30.56 \%$ \\
\hline Statutory & 477 & 477 & 477 & 477 & 542 & 542 & 542 & 643 & 634 & 634 & $32.91 \%$ \\
\hline \multicolumn{12}{|c|}{ 4-person households ( 2 adults +2 children up to the age of 14) } \\
\hline $\begin{array}{l}\text { Extreme } \\
\text { (minimum } \\
\text { of existence) }\end{array}$ & 1129 & 1196 & 1257 & 1336 & 1401 & 1486 & 1458 & 1472 & 1486 & 1571 & $39.15 \%$ \\
\hline Relative & 1676 & 1709 & 1795 & 1863 & 1866 & 1906 & 1926 & 1982 & 2080 & 2157 & $28.70 \%$ \\
\hline Statutory & 1404 & 1404 & 1404 & 1404 & 1824 & 1824 & 1824 & 2056 & 2056 & 2056 & $46.43 \%$ \\
\hline
\end{tabular}

Source: own elaboration based on Statistics Poland data (2009-2018).

The absolute approach raises the question of the criteria adopted for determining poverty lines and their scope. As a consequence, Statistics Poland does not indicate which of the adopted levels of poverty is the most important - as none of them are of 
official nature - treating all three measurements equally and defining them collectively as the limits of economic poverty. However, we should note that this is not a fully multidimensional approach, as these indicators are not treated as subindices for the aggregate index. For the needs of the European Commission, Statistics Poland also conducts measurements in the field of in-depth material deprivation based on survey analysis and measurements of low work intensity. It seems that the adoption of these measures in Polish statistics would complement the picture of the extent of poverty in Poland.

Furthermore, Statistics Poland calculates the extent of multidimensional poverty by creating a general indicator based on three complementary dimensions (Statistics Poland, 2018):

- income poverty, in which the monthly equivalent monetary income - i.e. income comparable between households with different demographic composition in the twelve months preceding the survey - was lower than the value recognized as the poverty line in relative terms, i.e. at $60 \%$ of the median equivalent income for the whole country;

- the poverty of living conditions, in which at least ten out of thirty poverty symptoms were observed, e.g. the quality of housing and the level of equipment in durable goods, no car for financial reasons, the lack of funds for medicine, the lack of money for entertainment and culture, the lack of money for at least one week of vacation once a year; and

- poverty of budget imbalances, in which account was taken of households' subjective perception of their material status, along with facts about budgetary difficulties of the household. A household was considered poor if it experienced at least four out of seven included symptoms, including arrears in payments.

\section{Data Sources and Research Methods}

The study of poverty differentiation was conducted on the basis of data on poverty in Poland made available by Statistics Poland. These data originate from Household Budgets Survey, a representative study aimed to monitor broadly understood living conditions of households. On the basis of the Household Budgets Survey, a government makes decisions in the field of national social policy. For example, the 2015 survey included 37,148 households (Statistics Poland, 2016). Variables related to relative, extreme, and statutory poverty for 2008-2017 on a voivodship scale were used in the analysis. 
In order to compare the level of poverty in the analyzed periods, we used the Friedman test. The Friedman test is a nonparametric equivalent of the one-way analysis of variance used when measurements of the tested variable are made several times $(k>=2)$ in different conditions. The condition for using this test is to measure analyzed variables at least on an ordinal scale. This test permits the verification of the research hypothesis that individual samples were taken from the same population or - more specifically - from populations with equal medians (with significance level $\alpha<0.05$ ). The rejection of the null hypothesis allows us to demonstrate that there are statistically significant differences between time periods in terms of the studied poverty variables. To check the null hypothesis, we use statistics based on the measure $\chi^{2}$ (Stanisz, 2006):

$$
\chi^{2}=\frac{12}{n k(k+1)} \sum_{i=1}^{k} R_{i}^{2}-3(k+1) n,
$$

in which

$R_{\mathrm{t}}$ is the sum of ranks of the ith measurement,

$k$ is the number of groups (measurements),

$n$ is the sample size.

Post-hoc analyses were performed using the Bonferroni test (Armstrong, 2014).

The spatial analysis of poverty was conducted on the basis of cluster analysis. This is one of the taxonomic methods whose purpose is to create sets of objects that will be as homogeneous as possible due to the similarity of the internal structure of the variables that characterize these objects. This comes down to such a grouping of objects in which conditions of homogeneity (objects belonging to the same group should be as similar as possible) and heterogeneity (objects belonging to different groups should be as dissimilar as possible) are met at the same time. Cluster analysis can be performed on the basis of a number of different grouping methods, among which we distinguish hierarchical, optimizational, iterative, area-related, and other methods. Cluster analysis using the Ward method was employed to identify groups of voivodships similar in terms of the extent of poverty during the scrutinized period (Panek and Zwierzchowski, 2013a).

All statistical analyses were made using the IBM SPSS Statistics 25 and Statistica 13.3 packages. 


\section{The Regional Differentiation of Poverty in Poland: Research Results}

\section{Extreme Poverty}

Table 2 presents descriptive statistics regarding extreme poverty rates in 2008-2017. In terms of the extent of extreme poverty, the highest averages refer to 2011-2014 and the lowest to 2016-2017. Let us note the large range in the examined variable. The difference between the poverty rate in the voivodship with the largest and smallest percentage of extremely poor households in the period under consideration is always above 6.5 percentage points (pp). The highest diversity was observed in 2014, when it exceeded $10 \mathrm{pp}$. In 2014, the highest median rate of extreme poverty was also observed. The studied variable is characterized by right-hand asymmetry. This means that in at least half of the voivodships, the value of extreme poverty is lower than the average for the whole country.

Table 2. Descriptive statistics of extreme poverty rate in Poland in 2008-2017

\begin{tabular}{|c|c|c|c|c|c|c|c|c|c|c|}
\hline $\begin{array}{c}\text { Descriptive } \\
\text { statistics }\end{array}$ & 2008 & 2009 & 2010 & 2011 & 2012 & 2013 & 2014 & 2015 & 2016 & 2017 \\
\hline Average & 5.98 & 6.09 & 6.23 & 7.28 & 7.36 & 7.93 & 8.21 & 7.09 & 5.19 & 4.61 \\
\hline Median & 5.35 & 5.80 & 5.50 & 7.25 & 6.60 & 7.80 & 7.90 & 7.15 & 4.75 & 3.85 \\
\hline $\begin{array}{l}\text { Standard } \\
\text { deviation }\end{array}$ & 2.44 & 2.15 & 2.19 & 2.77 & 2.72 & 2.37 & 2.77 & 2.77 & 2.27 & 2.16 \\
\hline Skewness & 0.58 & 0.53 & 0.58 & 0.21 & 0.79 & 0.64 & 0.92 & 0.33 & 0.45 & 0.45 \\
\hline Kurtosis & 0.17 & -0.20 & -1.10 & -1.45 & -0.15 & -0.14 & 0.64 & -0.74 & -1.19 & -1.13 \\
\hline Range & 9.50 & 7.70 & 6.30 & 8.30 & 9.00 & 8.30 & 10.10 & 9.10 & 6.80 & 6.90 \\
\hline Minimum & 1.80 & 2.90 & 3.60 & 3.10 & 4.50 & 4.90 & 4.70 & 3.40 & 2.20 & 1.80 \\
\hline Maximum & 11.30 & 10.60 & 9.90 & 11.40 & 13.50 & 13.20 & 14.80 & 12.50 & 9.00 & 8.70 \\
\hline
\end{tabular}

Source: own elaboration.

In the analyzed period, the average rate of extreme poverty ranged from $4.61 \%$ in 2017 to $8.21 \%$ in 2014. As demonstrated in Figure 1, 2008-2014 saw an increase in the percentage of households at risk of extreme poverty by $2.23 \mathrm{pp}$, which is equivalent to a $37 \%$ increase. As of 2015 , the trend reversed, and the extent of extreme poverty risk began to decrease. In the last of the surveyed years (2017) decreased by $4.61 \%$ and lowered by 1.37 pp compared to 2008. Compared to 2014, when the highest average 
rate of extreme poverty was observed, 2017 showed a decrease of $44 \%$. The statistical significance of differences in the level of the discussed variable for individual periods $(2008-2017)$ is confirmed by the Friedman test $\left(\lambda^{2}(9)=68.13 ; p<0.001\right.$.

Figure 1. The average rate of extreme poverty in 2008-2017 in Poland (data for 16 voivodships)

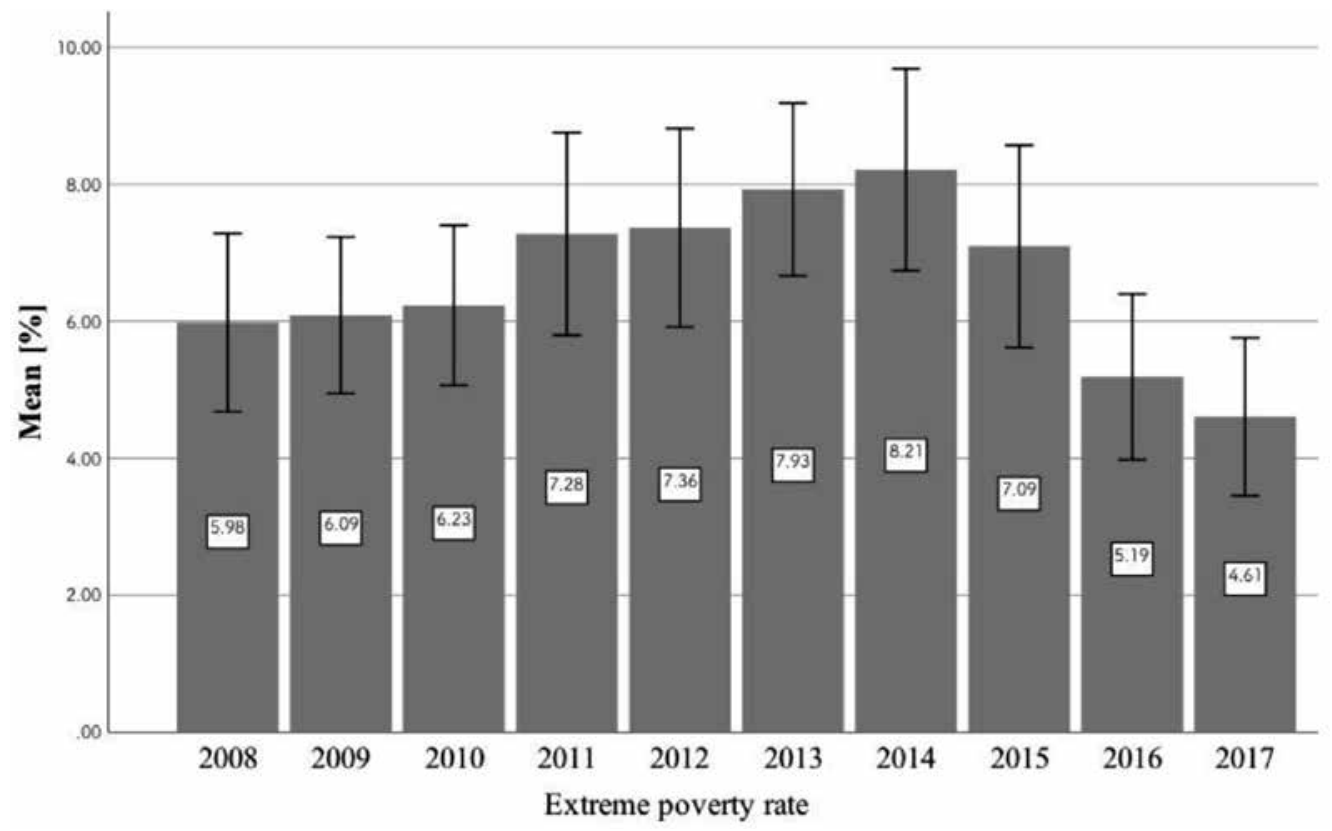

Source: own elaboration.

Post-hoc analysis showed that:

a) The percentage of households that experienced extreme poverty in 2014 was statistically significantly higher compared to 2008, 2009, 2010, 2011, 2016, and 2017.

b) The average extent of extreme poverty in 2013 was statistically significantly higher compared to 2008, 2009, 2016, and 2017.

\section{Relative Poverty}

The values of the scope of relative poverty in all researched years were higher than in extreme poverty, which resulted from the fact that the limit of relative poverty - calculated as $50 \%$ of the average equivalent expenditure of all households for a given country - is higher than the extreme poverty line. The highest averages regarding the 
rate of relative poverty concerned 2008-2011, while the lowest - 2016-2017 (see Table 3). In the case of relative poverty, the range between the lowest and the highest value in a given period was also much higher than for extreme poverty. The highest range was observed in 2008 and 2011 (16 and 16.1 pp, respectively) and the lowest in 2016 (13.3 pp).

Considering relative poverty (Figure 2), the highest rate in the analyzed period was recorded in 2010: on average, $18.67 \%$ of households this year realized expenditure at a level lower than half of the average household expenditure for all of Poland. The following years brought a decline in the extent of relative poverty. In 2017, a decrease of $4.46 \mathrm{pp}$ was observed, which means a decrease of $24 \%$. The statistical significance of the diversity of relative poverty in the period under study is confirmed by the Friedman test $\left(\lambda^{2}(8)=42.35 ; \mathrm{p}<0.001\right)$.

Figure 2. The average rate of relative poverty of voivodships in 2008-2017 in Poland (data for 16 voivodships)

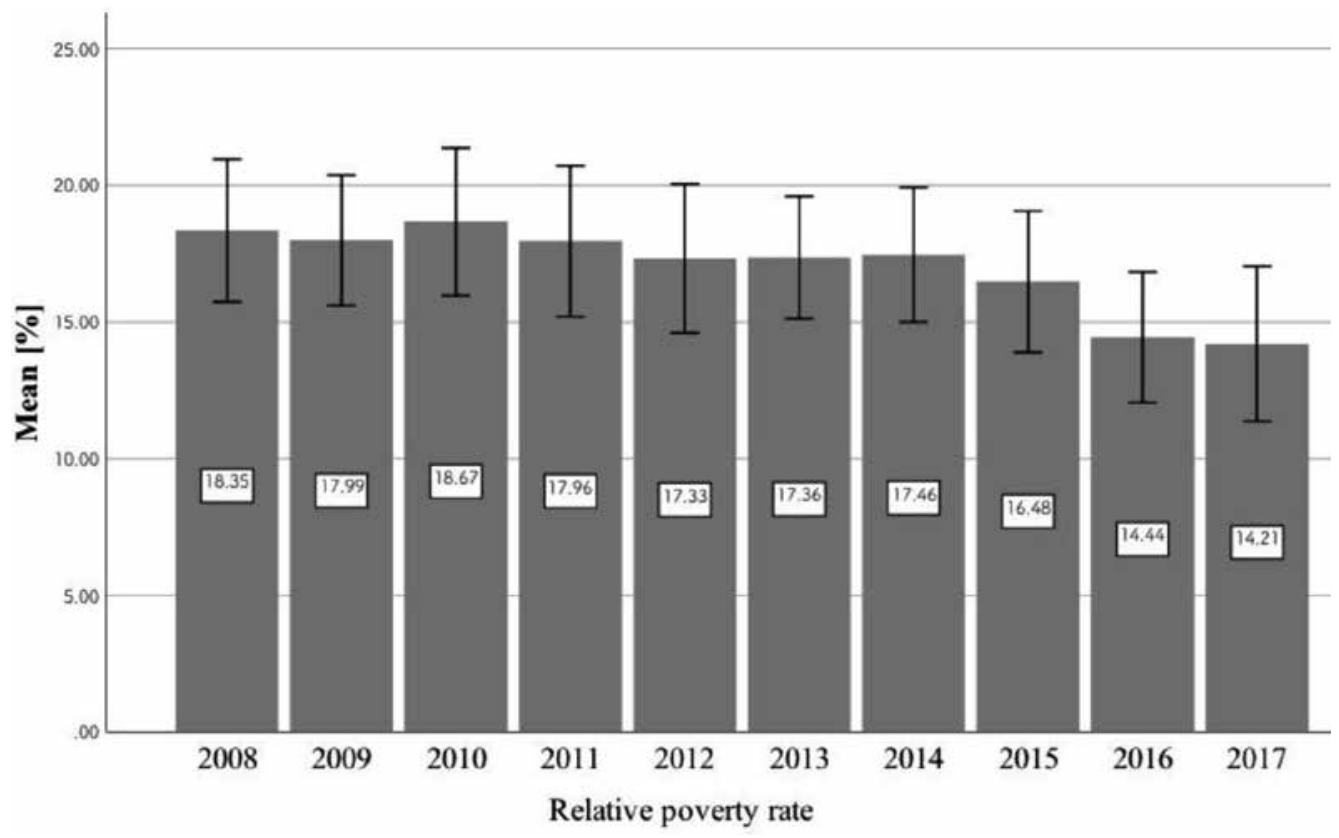

Source: own elaboration. 
Table 3. Descriptive statistics of the relative poverty rate in Poland in 2008-2017

\begin{tabular}{|c|c|c|c|c|c|c|c|c|c|c|}
\hline $\begin{array}{c}\text { Descriptive } \\
\text { statistics }\end{array}$ & 2008 & 2009 & 2010 & 2011 & 2012 & 2013 & 2014 & 2015 & 2016 & 2017 \\
\hline Average & 18.35 & 17.99 & 18.67 & 17.96 & 17.33 & 17.36 & 17.46 & 16.48 & 14.44 & 14.21 \\
\hline Median & 17.7 & 17.55 & 17.95 & 18.15 & 17.60 & 17.45 & 17.00 & 16.35 & 13.15 & 13.60 \\
\hline $\begin{array}{l}\text { Standard } \\
\text { deviation }\end{array}$ & 4.90 & 4.47 & 5.06 & 5.17 & 5.10 & 4.20 & 4.62 & 4.85 & 4.48 & 5.33 \\
\hline Skewness & 0.14 & 0.46 & 0.52 & 0.13 & 0.05 & 0.17 & 0.35 & 0.33 & 0.34 & 0.28 \\
\hline Kurtosis & -0.96 & -0.72 & -0.91 & -1.43 & -1.59 & -0.86 & -1.07 & -1.07 & -1.47 & -1.46 \\
\hline Range & 16.00 & 14.10 & 15.60 & 16.10 & 14.80 & 14.20 & 14.60 & 14.70 & 13.30 & 15.20 \\
\hline Minimum & 11.10 & 11.90 & 11.70 & 10.20 & 9.90 & 11.20 & 11.40 & 10.30 & 9.00 & 7.20 \\
\hline Maximum & 27.10 & 26.00 & 27.30 & 26.30 & 24.70 & 25.40 & 26.00 & 25.00 & 22.30 & 22.40 \\
\hline
\end{tabular}

Source: own elaboration.

\section{Statutory Poverty}

The highest average values in the statutory poverty rate regard the years 2013-2016, while the lowest - 2009-2012 (see Table 4). In this case, there also is a right-handed asymmetry, which means that the average rate of poverty is higher than the median. Compared to 2013, when statutory poverty concerned every fifth household in the poorest voivodship, in 2017, there was a decrease in the average, median, and the minimum and maximum value of statutory poverty.

Considering the extent of the last type of poverty - i.e. statutory poverty (Figure 3) - we should bear in mind that the statutory poverty line is an amount which, according to the Polish law, entitles the affected people to apply for social benefits. Thus, social benefits amounted to PLN 477 for single-person households in the first three quarters of 2012 and, since October 2012, it has been increased to PLN 542 and has remained unchanged for the next two years. The consequence of raising the statutory poverty threshold was the increase in its rate in 2013. A similar situation occurred in 2016, when - from October 2015 - the poverty threshold was raised to PLN 634 (Zasięg ubóstwa ekonomicznego, 2016, p. 2). However, let us note that in the latter case, the extent of poverty increased only by $0.31 \mathrm{pp}$. However, the largest decrease in the statutory poverty rate was recorded in 2017 - with the poverty threshold unchanged - which resulted from the introduction of the governmental program Rodzina 500+ (Family 500+) and the very low level of registered unemployment, which amounted 
to $6.6 \%$. We should underline that in the entire studied period, there was a systematic increase in the minimum wage: from PLN 1,126 gross in 2008 to PLN 2,000 gross in 2017. Particularly significant changes in the level of the minimum wage occurred since 2012 , when the increase compared to the previous year was on average $6 \%$. The largest increase was recorded in 2017 (8.11\%), which contributed to a significant decline in the extent of statutory poverty, next to the launch of the Rodzina 500+ program and the low level of unemployment. The significance of the difference in the levels of statutory poverty during the reviewed period is confirmed by the Friedman test $\left(\lambda^{2}(9)=108.04 ; p<0.001\right)$. The average statutory poverty rate in 2013-2016 turned out to be statistically significantly higher compared to other years.

Table 4. Descriptive statistics of statutory poverty rate in Poland in 2008-2017

\begin{tabular}{|c|c|c|c|c|c|c|c|c|c|c|}
\hline $\begin{array}{l}\text { Descriptive } \\
\text { statistics }\end{array}$ & 2008 & 2009 & 2010 & 2011 & 2012 & 2013 & 2014 & 2015 & 2016 & 2017 \\
\hline Average & 11.27 & 8.73 & 7.87 & 7.01 & 7.80 & 13.58 & 13.19 & 13.01 & 13.32 & 11.21 \\
\hline Median & 10.75 & 8.50 & 7.20 & 6.85 & 7.50 & 12.90 & 12.45 & 12.95 & 12.65 & 10.35 \\
\hline $\begin{array}{l}\text { Standard } \\
\text { deviation }\end{array}$ & 3.43 & 2.72 & 2.63 & 2.57 & 2.90 & 3.56 & 3.75 & 3.95 & 4.31 & 4.25 \\
\hline Skewness & 0.33 & 0.38 & 0.47 & 0.07 & 0.65 & 0.18 & 0.48 & 0.47 & 0.40 & 0.33 \\
\hline Kurtosis & -0.82 & -0.81 & -1.27 & -1.48 & -0.57 & -1.01 & -0.53 & -0.53 & -1.33 & -1.39 \\
\hline Range & 11.20 & 8.70 & 7.30 & 7.70 & 9.20 & 11.90 & 12.90 & 13.30 & 12.80 & 12.20 \\
\hline Minimum & 6.80 & 5.00 & 4.60 & 2.80 & 4.60 & 8.30 & 8.10 & 7.80 & 8.50 & 5.20 \\
\hline Maximum & 18.00 & 13.70 & 11.90 & 10.50 & 13.80 & 20.20 & 21.00 & 21.10 & 21.30 & 17.40 \\
\hline
\end{tabular}

Source: own elaboration.

The territorial diversity of three types of poverty rate in Poland studied in 2017 is presented in Figure 4. Both in extreme, relative, and statutory poverty, the highest rate is observed in voivodships located in eastern Poland, especially in podlasie and podkarpacie voivodships. On the other hand, voivodships with the lowest range of analyzed types of poverty are in the łódzkie and śląskie voivodships. 
Figure 3. The average statutory poverty rate in 2008-2017 in Poland (data for 16 voivodships)

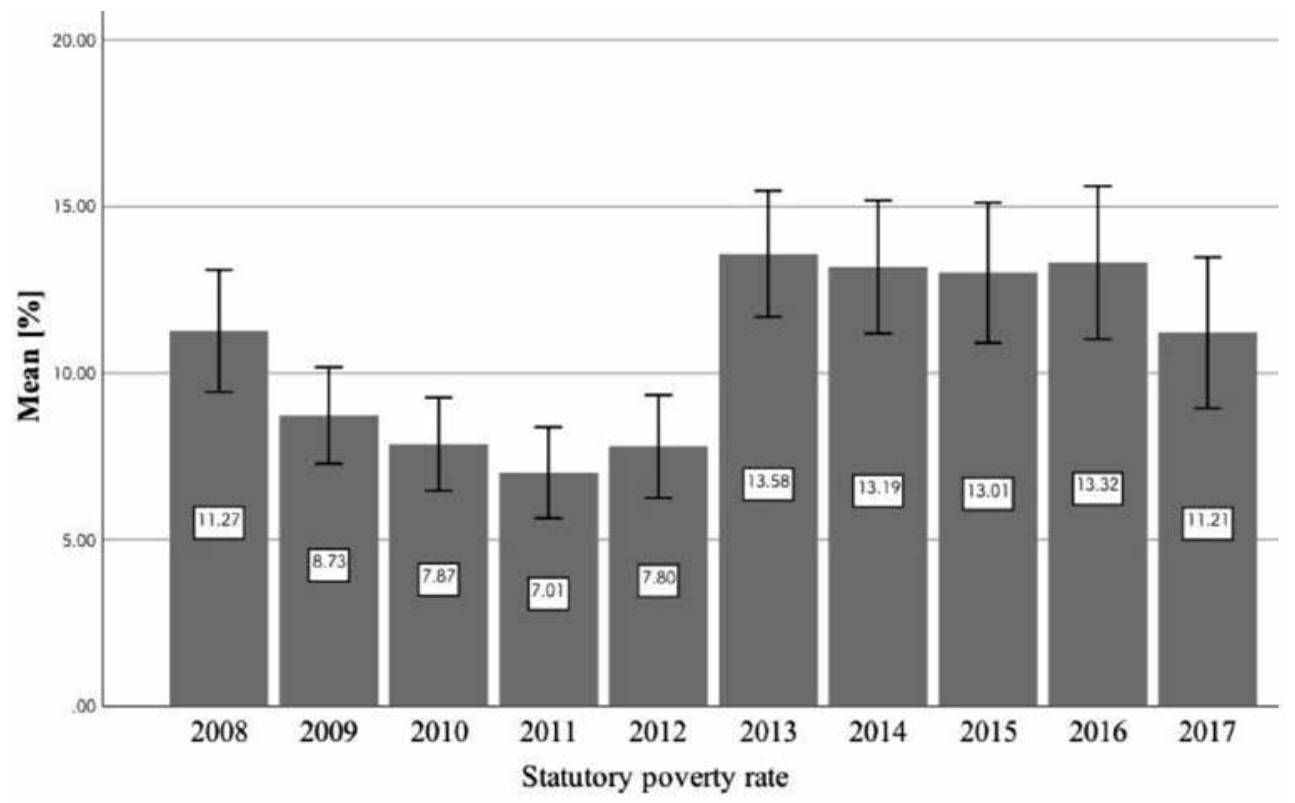

Source: own elaboration.

Figure 4. Spatial diversity of extreme, relative, and statutory poverty rate in Poland in 2017

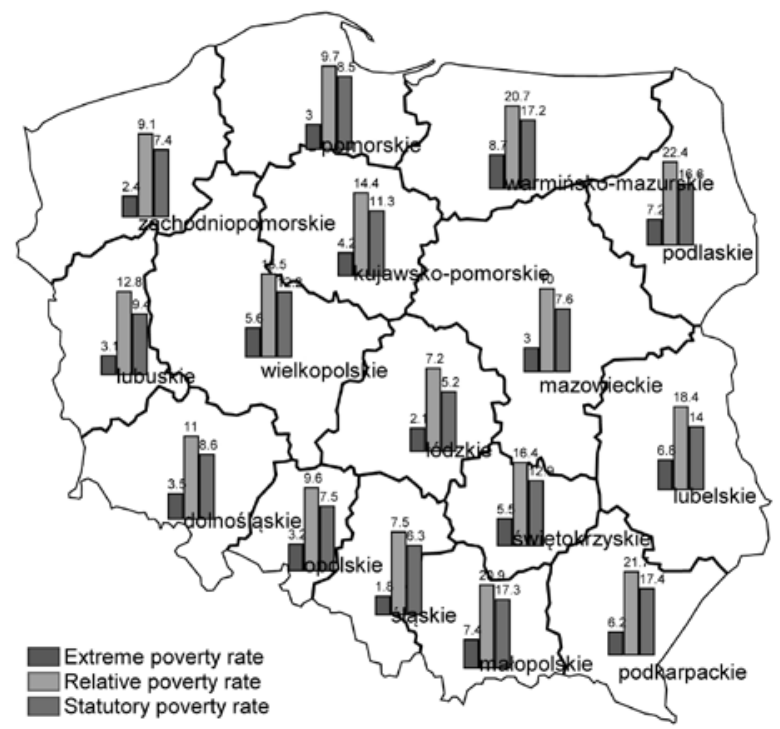

Source: own elaboration. 


\section{The Spatial Diversity of Extreme, Relative, and Statutory Poverty Rate in Poland: Cluster Analysis Results}

In order to conduct a spatial analysis of the diversity of extreme, relative, and statutory poverty rates in Poland, cluster analysis was conducted. The analysis included 16 voivodeships. The data used for analysis (values of the three mentioned indicators) refer to the period 2008-2017. Due to the limited volume of the article, the results of cluster analysis are presented for the first and last analyzed year. The performed analysis allowed us to distinguish three clusters in 2008 and four clusters in 2017 due to the extent of extreme, statutory, and relative poverty (Figure 5).

Figure 5. Results of cluster analysis in voivodships using the Ward method in 2008 and 2017
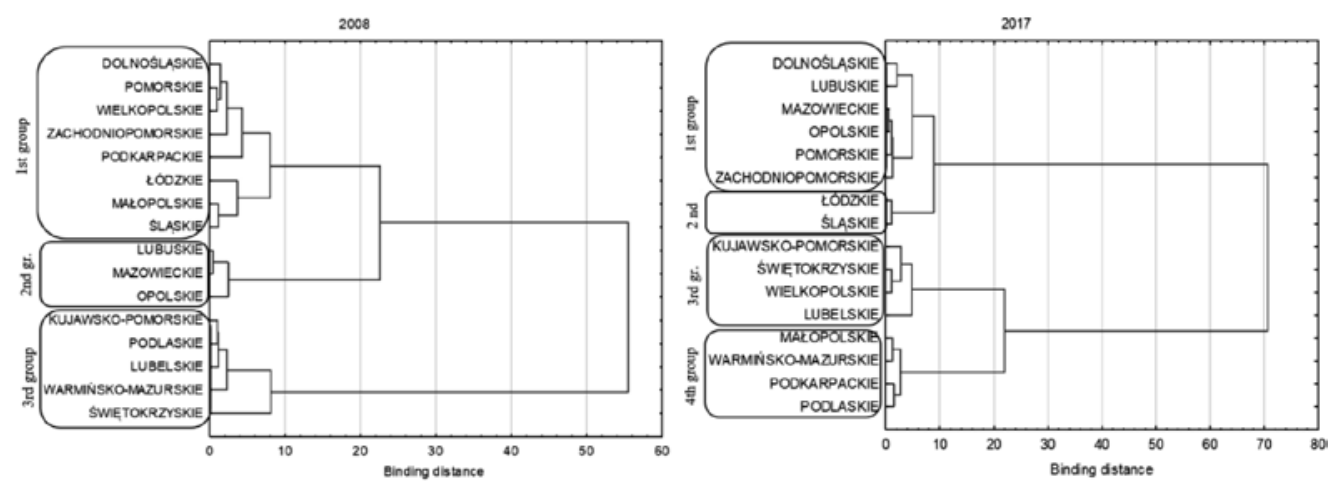

Source: own elaboration.

In 2008-2011, there emerged a division of voivodships into three groups. Starting from 2012, we observed a division into four groups. In 2008, the group of voivodeships for which poverty was the biggest problem included kujawsko-pomorskie, lubelskie, podlaskie, świętokrzyskie, and warmińsko-mazurskie voivodeships. In 2017, the voivodeships most affected by poverty included małopolskie, podkarpackie, podlaskie, and warmińsko-mazurskie.

In the group of voivodships most affected by poverty in $2008\left(3^{\text {rd }}\right)$, the extreme poverty rate was three times higher than in the second group, while the average relative poverty rate was twice as high (Table 5). Moreover, in the third group, over 15\% of households were entitled to apply for cash benefits under social assistance, while in the first and second groups, it was $10 \%$ and $7 \%$, respectively. In 2017, the average level of extreme poverty rate in the group of voivodships most affected by poverty was almost four times higher than in the group with the lowest percentage of households at risk of poverty. 
In the case of relative and statutory poverty rates, average values of these indicators were three times higher in the fourth group compared to the second. It follows that despite the drop in the average levels of all poverty indicators in 2017 compared to 2008, there is a noticeable increase in spatial differentiation in the level of indicators in question.

Table 5. Average values of the extent of extreme, relative, and statutory poverty in separate groups

\begin{tabular}{|l|c|c|c|}
\hline $\begin{array}{c}\text { Group } \\
\text { number }\end{array}$ & $\begin{array}{c}\text { Average rate of extreme } \\
\text { poverty [in \%] }\end{array}$ & $\begin{array}{c}\text { Average rate of relative } \\
\text { poverty [in \%] }\end{array}$ & $\begin{array}{c}\text { Average rate of statutory } \\
\text { poverty [in \%] }\end{array}$ \\
\hline & & $\mathbf{2 0 0 8}$ & \\
\hline 1st & 5.2250 & 17.2000 & 10.2750 \\
\hline 2nd & 3.0000 & 11.5667 & 6.9333 \\
\hline 3rd & 8.9800 & 24.2600 & 15.4600 \\
\hline & & 2017 & \\
\hline 1st & 3.0333 & 10.3667 & 8.1667 \\
\hline 2nd & 1.9500 & 7.3500 & 5.7500 \\
\hline 3rd & 5.5250 & 16.1750 & 12.6000 \\
\hline 4th & 7.3750 & 21.4250 & 17.1250 \\
\hline
\end{tabular}

Source: own elaboration.

In Poland, similarly to other countries, the territorial diversity of poverty is affected by numerous factors, including historical, geographical, economic, and political. This matter is more broadly discussed by Copus et al. (2015). The differences in poverty observed in Poland in individual voivodships are the result of socioeconomic changes that happened after the transition in 1989, in particular the introduction of market mechanisms to the economy. Poland's accession to the European Union also had a major impact on poverty. In consequence, there appeared new possibilities in the scope of economic development and fight against poverty and social exclusion, but also hope for reducing economic disparities. An example of such undertakings can be the realization of agendas for Eastern Poland, along with investment programs for, e.g., the zachodniopomorskie and lubuskie voivodships (Golinowska, 2018).

The conducted research explicitly indicates that voivodships with higher poverty rates mainly include regions located in eastern Poland with a low GDP (third and fourth group; Figure 5, Table 5). These groups are dominated by voivodships whose share in 
the creation of GDP in 2017 was the lowest: podkarpackie - 3.9\%, lubelskie - 3.8\%, warmińsko-mazurskie $-2.6 \%$, świętokrzyskie $-2.3 \%$, podlaskie $-2.2 \%$ (Wstępne szacunki produktu, 2019). In the case of the świętokrzyskie voivodship, this may stem from its demographic structure. On average, the region is inhabited by the oldest population, not only in Poland but also in the whole EU. Throughout many years, this region was the area of outflow of people in search of jobs and better living conditions, while financial support and the inflow of foreign capital are relatively very low (Golinowska, 2018). On the other hand, in the case of the warmińsko-mazurskie voivodeship, the low share in GDP may be due to the lowest indicators of economic activity on the scale of the entire country. The situation stems from the transition period and the related liquidation of many state-owned farms and forestry holdings. Indeed, we might say that the high degree of economic inactivity is a social issue in this the warmińsko-mazurskie voivodeship. The low intensity of household employment as the determinant of poverty was indicated by Szymkowiak et al. (2014).

The group of voivodships with lower poverty rates is dominated by voivodships with large and strong centers (e.g. mazowieckie, dolnośląskie, śląskie, łódzkie). Among voivodeships of this nature, only the małopolskie and wielkopolskie voivodships in 2017 were characterized by the greater extent of poverty. This may be due to the fact that they have a relatively sizeable shadow economy. According to the research of the Institute for Economic Forecasting and Analysis, in 2017 the shadow economy amounted to PLN 35.6 billion (15.3\%) in the wielkopolskie voivodship, and PLN 33.2 billion (17.2\%) in the małopolskie voivodship. Thus, both voivodships ranked respectively third and fourth in terms of the size of the shadow economy in Poland (Fundowicz et al., 2019, p. 27-28).

An important factor affecting the extent of poverty is the place of residence. In voivodships with the dominant percentage of the population inhabiting rural areas (podkarpackie, świętokrzyskie, lubelskie, małopolskie) the extent of poverty is higher. This is confirmed by research conducted by Bird (2019) and is due to two main reasons. First, the average disposable income of municipal households per capita is more than $30 \%$ higher than that of rural households. The highest share of the population working in low-yield agriculture is in the lubelskie voivodship (Golinowska, 2018). The second reason is the high level of unemployment among people living in rural areas. The percentage of registered unemployed workers among the rural population is the highest in the south-eastern region and, in 2017, it amounted to over $60 \%$ in the podkarpackie voivodeship. In the świętokrzyskie, warmińsko-mazurskie, małopolskie, and lubelskie voivodeships, over half of the people registered as unemployed were living in rural areas. In turn, in voivodships with a lower scale of poverty (łódzkie, śląskie; Figure 5; second group in Table 5), this percentage does not exceed 30\% (Ministerstwo Rolnictwa 
i Rozwoju Wsi, 2019). This problem was analyzed in detail in The Territorial Dimension of Poverty (2014). Registered unemployment in the countryside is often accompanied by hidden unemployment, consisting in farmers employing household members, mainly in family farms, although their work does not affect the increase in the level of production. To the greatest extent, this phenomenon concerns eastern Poland. It is estimated that the podkarpackie, warmińsko-mazurskie, and mazowiecke voivodships have from $9 \%$ to $11 \%$ of total hidden unemployed persons (Ministerstwo Rolnictwa i Rozwoju Wsi, 2019).

However, it is difficult to clearly establish the factors determining the division of voivodships. Undoubtedly, the level of GDP per capita is of key importance, but equally substantial are factors such as the level of unemployment, the size of the shadow economy, and geographical location. The level of poverty in voivodships is often determined by individual qualities, characteristic of a given region. Moreover, we should remember that the spatial diversity of poverty changes over time and, hence, should be subject to constant monitoring in order to properly design public policies and, consequently, allocate funds to combat poverty in accordance with the needs.

\section{Conclusion}

The conducted analyses reveal significant differences in the level of extreme, relative, and statutory poverty rate in 2008-2017 in Poland. The percentage of households experiencing extreme poverty increased until 2014. From the following year, the extent of extreme poverty began to decrease. In 2017, the lowest level was recorded in the period considered $-4.61 \%$ - which is 3.6 pp lower compared to 2014 . As far as relative poverty is concerned, it fell gradually throughout the entire analyzed period and amounted to $4.14 \mathrm{pp}$. However, we should note that there were years in which there was a slight increase compared to the previous year (e.g. in 2010). The largest one-off decrease was recorded in 2016; by 2.04 pp compared to the previous year. It is most challenging to clearly determine the direction of changes in the case of statutory poverty. While the extent of this poverty decreased in 2008-2011, the following years saw an increase, until 2013, by 6.57 pp in 2013 compared to 2011. In 2014-2017, the scope of statutory poverty in Poland decreased. Moreover, we should note that changes in the amount entitling one to apply for social assistance benefits (poverty line) had a significant impact on fluctuations in statutory poverty. Therefore, we may conclude that the adopted definition is crucial in the analysis of poverty, based on which changes not only the poverty range in the period under study (static approach) but also the direction of changes over time (dynamic approach). 
Like as in the case of differentiation in time, the extent of individual kinds of poverty is substantially differentiated in individual voivodeships. Cluster analysis demonstrated the existence of four groups of voivodships. In the case of all three types of poverty, voivodships with the low scale include dolnośląskie, lubuskie, łódzkie, mazowieckie, opolskie, śląskie, pomorskie, and zachodniopomorskie (group one and two). Such a spatial distribution of poverty in Poland indicates higher poverty in voivodships located in eastern Poland and lower poverty in voivodships with large urban (economic) centers. While in the case of the longitudinal dimension, the adopted definition of poverty - and thus the method of its measurement - significantly influenced the assessment of poverty extent over time, in the case of spatial analysis, the choice of indicator does not substantially affect the relative assessment of poverty level in individual voivodships. This means that regardless of the adopted indicator, it is possible to clearly identify the voivodships most and least affected by the problem of poverty.

The outcomes of the study are confirmed in the publications of Statistics Poland, which show that in Poland, the differentiation of poverty depends, among other things, on the place of residence defined by city class. In light of the study, the most obvious differences were observed in the case of relative income poverty. The rural population was the most affected by this form of poverty whereas, in cities, the extent of income poverty is inversely proportional to the size of the city. While in the largest cities with a population of at least 500,000 inhabitants, about $5 \%$ of households were at risk of income poverty, in rural areas this indicator reached the value of about $21 \%$, while in the smallest cities (with a population of less than 20,000) - almost 13\% (Statistics Poland, 2018).

As mentioned above, the place of residence and geographical location can affect the level of poverty (cf. Banerjee and Duflo, 2007; Bird, 2019), but it requires a thorough, in-depth analysis of such factors as the degree of industrialization, the type, number, and size of workplaces, and the level of living costs in the analyzed region (spatial poverty traps). As a consequence, the absolute and relative measure of poverty returns, but only in the objective approach, which is easier to evaluate and bears fewer risks of mistakes. Moreover, objective poverty may result from changes in the labor market, that is why it would be so important to add in a future study the division of poverty by duration, indicating temporary and long-term poverty.

The problem of the absolute and relative measure of poverty is twofold (Golinowska et al., 2005; Topińska, 2008; Haughton and Khandker, 2009). It seems that in the context of combating poverty at the European Union level, we must find the factors that define poverty mainly in absolute terms - but as a multidimensional definition of 
poverty - which will allow the community to be treated as a single organism and alleviate disparities between all EU regions (cf. Panek and Zwierzchowski, 2013). However, one relative measure of poverty could be chosen additionally, but for the entire European Union as one organism (not from the perspective of a single Member State), with purchasing power parity and standard of living taken into account. In turn, the relative and absolute approaches should be used from the viewpoint of national social policy, in which the government could dispose of the necessary instruments of direct response in the form of social transfers and tax allowances.

In conclusion, we should note that the conducted research can constitute the basis for further in-depth analyses. It seems particularly interesting to expand the study with spatial differentiation of the depth and severity of poverty of Polish households, with a particular emphasis on the elderly. Future research should verify what the differences in poverty rates among individual regions of the European Union are. The above research on poverty at the level of Poland's voivodships indicated that since the strategic goal of the European Union is sustainable growth, when planning the new Multiannual Financial Framework in the near future, the European Commission should point to the level of poverty in regions as one of the determinants of the amount of EU assistance in the fight against poverty and social exclusion.

\section{Acknowledgement}

The publication was financed by the subsidy granted to the Cracow University of Economics (Potencjał Programme).

\section{$\underline{\text { References }}$}

Armstrong, R.A. (2014). When to use the Bonferroni correction. Ophthalmic and Physiological Optics, 34(5), https://doi.org/10.1111/opo.12131.

Auleytner, J. (2002). Polityka społeczna, czyli ujarzmianie chaosu socjalnego. Warszawa: Wydawnictwo Wyższej Szkoły Pedagogicznej Towarzystwa Wiedzy Powszechnej.

Bird, K. (2019). Addressing Spatial Poverty Traps. Chronic Poverty Advisory Network. London: Overseas Development Institute.

Banerjee, A. and Duflo, E. (2007). The Economic Lives of the Poor. Journal of Economic Perspectives, 21(1), 141-167. https://doi.org/10.1257/jep.21.1.141.

Copus, A., Melo, P.C., Kaup, S., Tagai, G. and Artelaris, P. (2015). Regional poverty mapping in Europe - Challenges, advances, benefits and limitations. Local Economy, 30(7), 742-764. https://doi.org/10.1177/0269094215601958.

Fundowicz, J., Łapiński, K., Wyżnikiewicz, B. and Wyżnikiewicz, D. (2019). Szara strefa. Warszawa: Instytut Prognoz i Analiz Gospodarczych. 
Fusco, A., Guio, A.C. and Marlier, E. (2017). Monitoring social inclusion in Europe 2017 Edition. Eurostat. Luxembourg: Publications Office of the European Union.

Golinowska, S., Tarkowska, E. and Kopińska, I. (2005). Ubóstwo i wykluczenie społeczne: badania, metody, wyniki. Warszawa: IPiSS.

Golinowska, S. (2018). O polskiej biedzie w latach 1990-2015. Definicje, miary i wyniki. Warszawa: Wydawnictwo Naukowe Scholar.

Haughton, J. and Khandker, S.R. (2009). Handbook on poverty and inequality. World Bank, Washington D.C.

Jenkins, S.P. (2011). Changing Fortunes: Income Mobility and Poverty Dynamics in Britain. Oxford: Oxford University Press, https://doi.org/10.1093/acprof:oso/9780199226436.001.0001

Lehtonen, R. and Veijanen, A. (2012). Small Area Estimation Poverty by Model Calibration. Journal of The Indian Society of Agricultural Statistics, 66(1), 125-133.

Lelkes, O., Medgyesi, M. and György, T.I. (2009). The Factors Affecting the Risk of Poverty and Inequalities in Income Distribution. In: T. Ward, O. Lelkes, H. Sutherland et al. (eds.), European Inequalities: Social Inclusion and Income Distribution in the European Union. Budapest: TÁRKI Social Research Institute.

Madanipour, A., Shucksmith, M. and Talbot, H. (2015). Concepts of poverty and social exclusion in Europe. Local Economy, 30(7), 721-741, https://doi.org/10.1177/0269094215601634.

Ministerstwo Rolnictwa i Rozwoju Wsi (2019). Diagnoza sytuacji społeczno-gospodarczej rolnictwa obszarów wiejskich i rybactwa w Polsce. Dokument służący opracowaniu strategii zrównoważonego rozwoju wsi, rolnictwa i rybactwa 2030. Warszawa.

Molina, I., Rao, J.N.K. and Nandram, B. (2014). Small Area Estimation of General Parameters with Application to Poverty Indicators: A Hierarchical Bayes Approach. The Annals of Applied Statistics, 8(2), 852-885, https://doi.org/10.1214/13-AOAS702.

Nalaskowski, F. (2007). Ubóstwo a wykluczenie społeczne jako problem dla edukacji. Olsztyn: Zespół Monitorowania Zmian w Kulturze i Edukacji.

Panek, T. (2010). Multidimensional approach to poverty measurement: fuzzy measures of the incidence and the depth of poverty. Statistics in Transition, 11(2), 361-379.

Panek, T. and Zwierzchowski, J. (2013). Porównawcza analiza sfery ubóstwa w krajach UE w ujęciu regionalnym. Zeszyty Naukowe Instytutu Statystyki i Demografii SGH, 35, Warszawa: 1-117.

Panek, T. and Zwierzchowski, J. (2013a). Statystyczne metody wielowymiarowej analizy porównawczej. Teoria i zastosowania. Warszawa: Oficyna Wydawnicza Szkoły Głównej Handlowej.

Program Operacyjny Polska Wschodnia 2014-2020 (2020). https://www.polskawschodnia.gov.pl/media/85203/POPW_10022020.pdf.

Program Operacyjny Rozwój Polski Wschodniej 2007-2013. Narodowe Strategiczne Ramy Odniesienia 2007-2013. Szczegółowy opis osi priorytetowych (2012). Ministerstwo Rozwoju Regionalnego. Warszawa.

https://www.polskawschodnia.2007-2013.gov.pl/Dokumenty/Lists/Dokumenty\%20programowe/ Attachments/89/SOOP_120912.pdf.

Quintano, K.C., Castellano, R. and Punzo, G. (2007). Estimating Poverty in the Italian Provinces using Small Area Estimation Models. Metodološki zvezki, 4(1), 37-70.

Rusnak, Z. (2011). Pomiar ubóstwa i wykluczenia społecznego - problemy metodologiczne. Zeszyty Naukowe Wyższej Szkoły Bankowej we Wrocławiu, 20, 387-408.

Ruzik, A. and Styrc, M. (2006). Przeciwdziałać drodze od ubóstwa do wykluczenia społecznego. Polityka Społeczna, 3(384), 34-38. 
Salejko-Szyszczak, I. and Szczepaniak, M. (2017). The risk of poverty and social exclusion in Poland in the period 2006-2015 in the comparison to the European Union countries. Ekonomia i Prawo, 16(2), 201-217. http://dx.doi.org/10.12775/EiP.2017.014.

Sączewska-Piotrowska, A. (2016). Dynamika ubóstwa w miejskich i wiejskich gospodarstwach domowych. Wiadomości Statystyczne, 7, 39-59, https://doi.org/10.5604/01.3001.0014.1038.

Sen, A. (2000). Development as freedom. New York: Alfred A. Knopf.

Stanisz, A. (2007). Przystępny kurs statystyki z zastosowaniem STATISTICA PL na przykładach z medycyny, t. 3, Analizy wielowymiarowe. Kraków: Statsoft Polska Sp. z o. o.

Statistics Poland (2016). Budżety Gospodarstw Domowych w 2015 r. Warszawa.

Statistics Poland (2018). Różne oblicza ubóstwa w Polsce w 2015 r. i 2018 r. na podstawie Badania spójności społecznej. Warszawa.

Statistics Poland (2009-2018). Zasięg ubóstwa ekonomicznego w Polsce w latach 2008-2017. Warszawa.

Statistics Poland (2019). Zasięg ubóstwa ekonomicznego w Polsce w 2018 r. (na podstawie wyników badania budżetów gospodarstw domowych). Warszawa.

Statistics Poland (2019). Wstępne szacunki produktu krajowego brutto w przekroju regionów w 2017 r. Warszawa.

Szarfenberg, R. (2012). Ubóstwo i wykluczenie społeczne w Polsce. Pomiar, wyjaśnianie, strategie przeciwdziałania, Friedrich-Ebert-Stiftung, Przedstawicielstwo w Polsce wspólnie z Fundacją Międzynarodowe Centrum Badań i Analiz (ICRA ), Warszawa.

http://rszarf.ips.uw.edu.pl/pdf/uiws2012a.pdf.

Szymkowiak, M., Beręsewicz, M., Bieńkuńska, A., Jastrzębski, P., Józefowski, T., Klimanek, T., Kowalewski, J., Kraj, M., Łysoń, P., Małasiewicz, A., Młodak, A., Panek, T., Piasecki, T., Pietrzak, M. and Wawrowski, Ł. (2014). Pomiar ubóstwa na poziomie powiatów - etap I. Centrum Badań i Edukacji Statystycznej GUS. Jachranka.

Szymkowiak, M., Beręsewicz, M., Bieńkuńska, A., Jastrzębski, P., Jaworska, M., Józefowski, T., Klimanek, T., Kowalewski, J., Łysoń, P., Młodak, A., Panek, T., Piasecki, T., Pietrzak, M., Skrzypczak, A., Wawrowski, Ł. and Włodarczyk, A. (2015). Pomiar ubóstwa na poziomie powiatów - etap II. Centrum Badań i Edukacji Statystycznej GUS. Jachranka.

The Territorial Dimension of Poverty and Social Exclusion in Europe. Applied Research 2013/1/24. Draft Final Report (2014). Luxembourg: Nordregio and James Hutton Institute.

Topińska, I. (2008). Kierunki zmian w statystyce ubóstwa. In: I. Topińska, J. Ciecieląg and A. Szukiełojć-Bieńkuńska (eds.), Pomiar ubóstwa. Zmiany koncepcji i ich znaczenie. Warszawa: IPiSS.

Townsend, P. (1987). Deprivation. Journal of Social Policy, 16(2), 125-146. https://doi.org/10.1017/S0047279400020341.

Ulman, P., Ćwiek, M. (2014). Poverty of households due to their biological type in a multidimensional approach. Proceedings of the 8th Professor Aleksander Zelias International Conference on Modelling and Forecasting of Socio-Economic Phenomena. Cracow: Foundation of the Cracow University of Economics, 214-222.

Ward, T. (2009). Material deprivation. In: T. Ward, O. Lelkes, H. Sutherland et al. (eds.), European Inequalities: Social Inclusion and Income Distribution in the European Union. Budapest: TÁRKI Social Research Institute.

Whelan, C.T and Maître, B. (2010). Welfare regime and social class variation in poverty and economic vulnerability in Europe: an analysis of EU-SILC. Journal of European Social Policy, 20(4), 316-332. https://doi.org/10.1177/0958928710374378. 